\title{
MEMBANGUN NUANSA HOMEY DENGAN IMPLEMENTASI WARNA DINGIN DAN NETRAL DALAM PENYUTRADARAAN PROGRAM TV MAGAZINE “LIVING IN HEALTH”
}

\author{
Felicia Listyadesi \\ Agnes Widyasmoro \\ Andri Nur Patrio \\ Jurusan Film \& Televisi, Fakultas Seni Media Rekam, Institut Seni Indonesia Yogyakarta \\ Jl. Parangtritis km. 6.5 Yogyakarta Telp. (0274) 381047
}

\begin{abstract}
ABSTRAK
Program TV magazine "Living in Health" mengangkat tema gaya hidup sehat dengan nuansa homey dengan penerapan warna dingin dan netral. Nuansa homey dibangun untuk membuat suasana nyaman ketika melakukan gaya hidup sehat. Definition of ,homey" is comfortable or familiar like home (definisi homey adalah nyaman atau akrab seperti rumah). Healthty Lifestyle dipilih karena gaya hidup ini dipandang mahal dan sulit untuk diterapkan, tetapi program tv magazine "Living in Health" memberi informasi gaya hidup sehat praktis, murah, dan dapat dilakukan di rumah.

Pembangunan nuansa homey didukung dengan implementasi warna dingin yang netral yang merupakan karakter ketentraman. Warna dingin dan netral diterapkan dalam setting aristik, motion graphic, dan tata kostum. Warna-warna dingin sebagian besar digunakan dalam simbol kesehatan dan kealamian menjadi alasan utama dalam penerapannya.

Konsep penyutradaraan membangun nuansa homey dengan menerapkan setting dan implementasi warna pada property rumah. Program tv ini akan membawa penonton untuk dapat melakukan beragam aktivitas hidup sehat di rumah yang nyaman. Topik yang disajikan merupakan informasi yang diminati dan dekat oleh wanita sebagai segmentasi utama. Beberapa rubrik tentang healthy lifestyle disajikan dalam program tv ini. Efek yang ditimbulkan menggunakan warna dingin dan netral adalah perbedaan suasana setiap segmen dan rubrik yang disajikan. Memberikan energi yang berbeda pada setiap aktivitasnya.
\end{abstract}

kata kunci: magazine, homey, warna, healthy lifestyle, wanita

\section{Pendahuluan}

Makanan sehat adalah makan

yang mengandung zat-zat yang dibutuhkan oleh tubuh tetapi juga higienis, bergizi, dan berserat. Tubuh membutuhkan karbohidrat, protein, mineral, vitamin, dan lemak yang cukup. Mengatur kadar gizi yang terkandung dalam makanan dan terdapat banyak manfaat bagi tubuh kita. Mulai dari mendapatkan dan mempertahankan berat badan yang ideal, meningkatkan energi, meningkatkan daya pikir dan konsentrasi, mencegah penyakit kronis, dan masih banyak lagi. Gaya hidup dan gaya makan yang serba instan, tidak teratur, dan tidak sehat membuat hilangnya kemampuan ini. Banyak sekali menu makanan sehat yang dapat mengontrol pola makan, salah satunya dengan gaya makan eating clean.

Eating Clean adalah pola makan yang mengkonsumsi makanan paling alami dan tidak banyak diproses 
(makanan olahan), yaitu sedapat mungkin makanan yang berada di rantai makanan paling bawah. Memakan makanan dalam bentuk alam, otomatis asupan vitamin, mineral, dan zat-zat penting lainnya menjadi lebih tinggi dan lebih baik. (Bachrens, 2017:26)

Olahraga dapat dilakukan di mana saja, tidak hanya di tempat fitnes, stadion olahraga, dan lapangan. Olahraga juga tidak harus menggunakan alat-alat mahal dan lengkap. Olahraga dapat dilakukan di rumah dengan peralatan sederhana. Calisthenics atau lebih dikenal dengan home excercise menggunakan gerakan sederhana tetapi mempunyai banyak manfaat bagi kesehatan tubuh. Home excercise mempunyai beragam gerakan disesuaikan dengan kebutuhan untuk membentuk postur tubuh dengan mengandalkan berat badan.

Home excercise dapat dilakukan sebelum berangkat ke kantor, dengan memanfaatkan waktu yang singkat tanpa harus pergi ke luar ruangan atau ke tempat olahraga. Berolahraga saja tidak cukup untuk menjaga kesehatan dalam tubuh, namun juga harus diimbangi pola makan sehat.

Buah-buahan telah diakui kaya akan vitamin yang dibutuhkan tubuh. Vitamin yang dimiliki oleh buah-buahan juga diperlukan oleh kulit untuk menjaga kelembaban kulit, membuat kulit lebih cerah, bebas jerawat, dan banyak lagi.
Merawat kulit dengan bahan alami tentunya dapat dilakukan di rumah dengan biaya murah, dan dapat dilakukan kapan saja.

Menggabungkan olahraga dengan cara home excercise, makan makanan sehat dengan pola eat clean dan merawat kulit dengan buah-buahan sebagai bahan utama dapat menerapkan hidup sehat yang semuanya dapat dilakukan di rumah. Masyarakat di Indonesia sendiri belum terbiasa dengan gaya hidup sehat yang memakan waktu lebih lama. Gaya hidup yang serba cepat membuat masyarakat menginginkan hasil instan. Kebiasaan ini dapat diubah dengan membuat program televisi yang membahas gaya hidup sehat untuk masyarakat umum.

Nuansa homey membentuk suasana nyaman penonton yang diimplementasikan lewat warna-warna dingin \& netral menjadi penting karena dalam magazine membahas perawatan kesehatan yang membutuhkan kenyamanan, konsentrasi dan dapat membuat penonton bertahan lebih lama untuk menyaksikan program ini, sekaligus penonton dapat mengaplikasikan di rumah masing-masing. Nuansa homey yang diciptakan akan membuat penonton merasa nyaman.

Implementasi warna dingin dan netral akan diwujudkan dalam property yang ada di dalam setting tempat yang 
menunjukkan berada di satu rumah, background, wardrobe yang digunakan host, juga elemen motion graphic yang terdiri dari typografi, garis, shape, transisi, dan animasi sederhana. Program magazine "Living in Health" berisi tentang instruksional memasak, dan berolahraga, Video Tape (VT) info kesehatan, wawancara sumber ahli, dan voxpop mengenai kesehatan.

\section{Ide Penciptaan}

Ide awal dalam menciptakan program magazine ini dari keinginan diri sendiri untuk mengubah pola hidup sehat, tetapi kurangnya informasi dan tidak ada partner dalam melakukan pola hidup sehat menyebabkan semangat menurun. Informasi tentang gaya hidup yang sehat tersebut dirangkum dalam format program televisi magazine berjudul Living in Health. Living in Health adalah sebuah program magazine yang menyajikan informasi seputar kesehatan dengan mengajak para wanita membentuk pola hidup yang sehat. Acara ini dikemas dengan format magazine yang tersaji dalam beberapa rubrik dan sesuai tema dengan minat dari target penontonnya.

Program magazine "Living in Health" menyajikan informasi gaya hidup sehat yang mempunyai 4 (empat) rubrik di setiap episodenya dengan durasi 30 menit. Acara ini dipandu dengan host yang akan menghantarkan penonton menyaksikan liputan-liputan yang akan dibahas. Rubrik-rubrik yang dibahas meliputi pengetahuan tentang permasalahan yang ada di masyarakat khususnya wanita dan memberikan solusi mengenai gaya hidup sehat.

\section{Objek Penciptaan}

Hidup yang sehat dan tubuh yang bugar adalah keinginan setiap orang, untuk mencapainya perlu memperhatikan beberapa aktivitas yang mendukung. Olahraga yang cukup dan teratur, makanmakanan sehat dan bergizi yang diperlukan tubuh, istirahat yang cukup, menghentikan kebiasaan buruk, dan menghindari stres adalah aktivitas yang dapat mewujudkan hidup sehat yang optimal. Program magazine Living in Health akan membantu para wanita mewujudkan hidup sehat yang semuanya dapat dilakukan di rumah, dengan biaya murah, juga waktu yang singkat.

1. Gaya Hidup Sehat Gaya hidup sehat jika dijalankan terus menerus akan memberikan berdampak besar bagi tubuh. Banyak manfaat yang didapat, seperti memperoleh berat badan yang ideal, tubuh menjadi kuat, kulit dan rambut juga menjadi lebih sehat. Menerapkan gaya hidup sehat tidak hanya memberikan dampak pada tubuh, tetapi dampak positif juga didapat dari aspek psikologis. 
Menerapkan gaya hidup sehat memberikan efek positif pada diri sendiri dan lingkungan sekitar. Pengaruh positif yang diberikan gaya hidup sehat membuat orang yang melakukannya menjadi lebih semangat dalam beraktivitas dan lebih terstruktur. Gaya hidup adalah perilaku seseorang yang ditunjukkan dalam aktivitas, minat, dan opini khususnya yang berkaitan dengan citra diri untuk merefleksikan status sosialnya.

2. Kesehatan

Kesehatan adalah kebutuhan dasar manusia. Kesehatan merupakan keadaan sejahtera dari badan, jiwa, dan sosial yang memungkinkan setiap orang hidup produktif secara sosial, dan ekonomis. Kesehatan berkaitan erat dengan gaya hidup yang dilakukan setiap harinya.

\section{Analisis Objek Penciptaan}

1. Makanan Sehat

Program TV magazine ini akan membahas tentang makanan sehat, tentunya makanan sehat menjadi hal pokok untuk membentuk gaya hidup sehat. Episode pertama akan membahas tentang pola makan eating clean. Sekarang ini banyak pilihan aturan makan yang ada di masyarakat bertujuan untuk mencapai berat badan ideal, pola makan sehat, dan sebagainya.

Eating clean adalah cara makan makanan dengan mengutamakan makanan alami yang kaya akan serat, bukan makanan olahan/kemasan. Produk makanan yang mempunyai label alami, belum tentu alami karena mengandung banyak pengawet buatan, pewarna buatan, dan pemanis buatan.

\section{Kecantikan}

Perawatan menggunakan bahan-bahan alami dengan bahan yang dapat ditemui di rumah. Sayur mayur dan buah tidak hanya berguna untuk menutrisi tubuh, tetapi juga untuk nutrisi kulit. Kulit membutuhkan vitamin A, B kompleks, C, D, E dan K.

Episode pertama ini, beauty akan membahas tentang sayur kale yang dapat bermanfaat bagi kecantikan wanita. Sayur yang baik untuk dikonsumsi dan juga sebagai perawatan dari luar. Sayur kale merupakan superfood yaitu kelompok makanan yang padat nutrisi sehingga baik untuk tubuh

\section{Olahraga}

Berolahraga adalah sebuah kegiatan yang harus dilakukan untuk sehat. Tidak perlu olahraga yang ekstrem, tetapi hanya perlu 
olahraga yang teratur. Minimal 30 menit dalam sekali berolahraga, dan 5 kali dalam seminggu.

Plank merupakan gerakan olahraga yang mempraktekkan satu posisi statis dalam durasi tertentu yang memiliki banyak manfaat. Memiliki perut rata, lengan lebih kencang, tubuh menjadi fleksibel dan lebih banyak kalori terbakar jika menerapkan plank secara rutin.

\section{Mitos \& Fakta}

Banyak sekali pemahaman yang salah di masyarakat tentang hidup sehat dan masih berlangsung sampai sekarang. Pemahaman salah tersebut akan diberikan penjelasan yang tepat sehingga masyarakat memahami mana yang benar dan yang salah. Masyarakat akan mengubah kebiasaan yang salah dan mulai menerapkan dalam kehidupan sehari-hari beriringan dengan olahraga, makan-makanan sehat, dan perawatan tubuh yang sehat. Beberapa hal akan dibahas dalam rubrik ini.

\section{Kerangka Konsep}

Penyutradaraan dalam program magazine harus mampu memvisualisasikan konsep yang sudah dipersiapkan sehingga menghasilkan program yang berkualitas dan mampu diterima oleh target penontonnya. Teknik penyutradaraan magazine mengikuti gaya dan teknik penulisan berita tulis. Tetapi jika media cetak mengandalkan foto/gambar, magazine mengandalkan gambar/visual movement yang diimbuhi oleh naskah.

Magazine yang mengangkat tema seputar kesehatan akan menghadirkan beberapa narasumber seperti ahli gizi, private instructor, dan beberapa opini masyarakat. Narasumber yang terpercaya diharapkan mampu mendukung konten dalam rubrik yang ada dalam program tv ini.

\section{Program magazine "Living in} Health" dibagi menjadi empat rubrik. Dipandu oleh seorang host wanita yang juga memperhatikan gaya hidup sehat. Tasty \& Healthy \& Movement menjadi rubrik fix items, sedangkan rubrik Beauty dan Mitos \& Fakta menjadi rubrik flexible items.

$$
\text { Pengambilan gambar pada }
$$
program Living in Health akan menggunakan multicamera. Metode memfilmkan menggunakan master scene dan triple take. Master scene diterapkan ketika adegan-adegan yang dikira sulit untuk diulangi kembali, misalnya memasak. Sedangkan teknik triple take diterapkan ketika host memberikan penjelasan kepada penonton.

Penataan artistik dalam program ini memegang peranan penting, terutama setting utama berada di rumah. Pengambilan gambar menggunakan 
setting di rumah, aktivitas yang dilakukan lebih banyak dengan setting rumah. Setiap rubrik dalam program magazine menggunakan tempat yang berbeda-beda. Tetapi masih dalam satu rumah yang sama. Sehingga setiap set berkesinambungan satu sama lain. Rumah dipilih dengan design dapur yang berada tepat di samping living room, sedangkan taman belakang rumah berada di samping living room hanya dibatasi oleh pintu. Design ini merupakan karakteristik rumah minimalis yang meminimalisir sekat pada tata ruang sehingga terkesan lebih lapang.

Warna yang dominan dalam setting dapur lebih mengarah ke warna hijau mint tentunya menggunakan warna netral untuk mengimbangi warna. Warna hijau mint dapat membuat ruangan terasa segar dan menyejukkan. Warna hijau mint juga dapat berpadu dengan warna hijau dalam bahan masakan. Setting dapur yang akan menggabungkan warna hijau dan warna putih akan membuat gambar terkesan clean. Gambar yang clean mencerminkan dapur yang higienis. Rubrik “Tasty \& Healthy” menggunakan setting dapur.

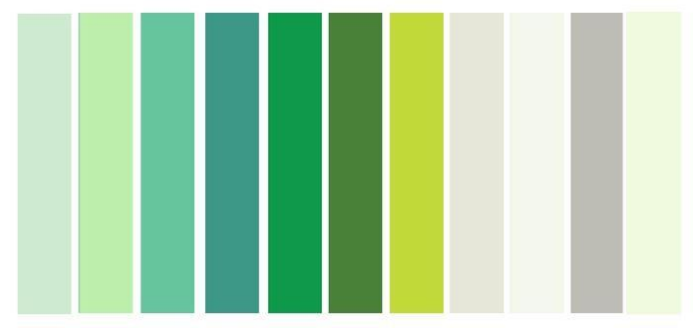

Gambar 1 palette warna set dapur

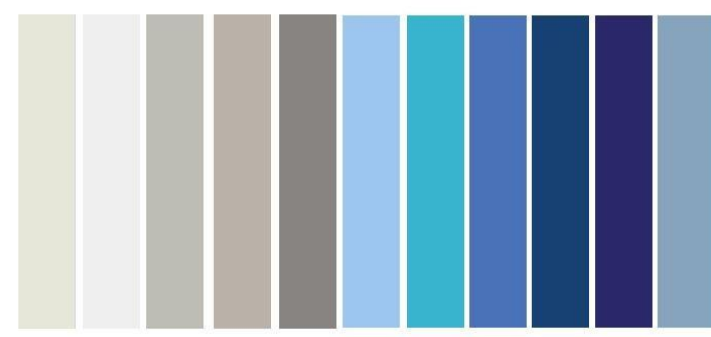

Gambar 2 color palette set living room

Rubrik "beauty" menggunakan living room, dalam set living room akan terlihat interior rumah disertai dengan furniture yang ada di dalamnya. Salah satu furniture yang menonjol adalah sofa.

Warna hijau dalam rubrik movement didapat dari banyaknya tanaman yang ada di dalam set. Setting berada di taman akan memperlihatkan back to nature sehingga memperlihatkan kealamian. Setting dengan tema alami menciptakan suasana yang menyegarkan, banyaknya tumbuhan yang dimasukan dalam set merupakan penanda udara yang selalu fresh.

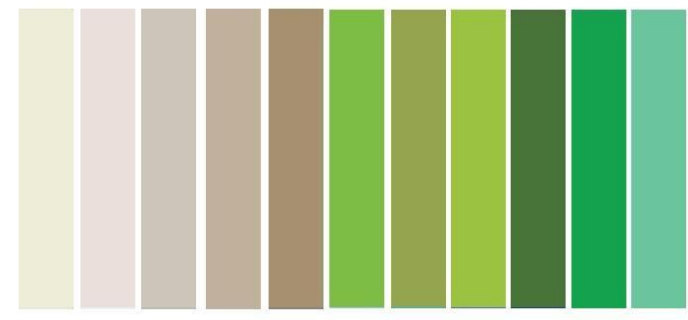

Gambar 3 color palette set backyard

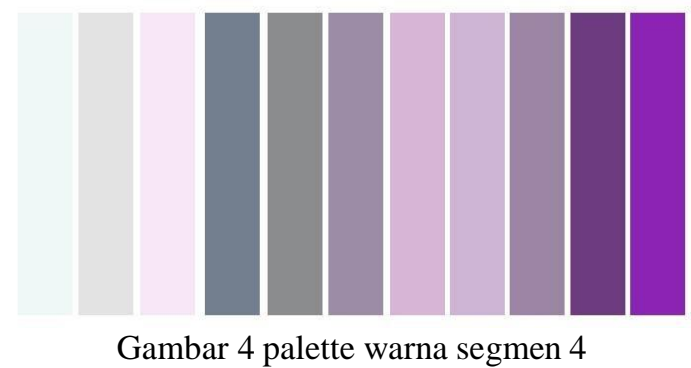


Segmen mitos dan fakta memberikan penjelasan tentang suatu masalah yang terkadang salah dipahami oleh masyarakat. Warna ungu memberikan kesan kepercayaan, sehingga masyarakat dapat memahami dan percaya terhadap penjelasan yang diberikan oleh narasumber.

\section{Desain Produksi}

1. Tema : Gaya Hidup Sehat

2. Judul : Living in Health

3. Episode : Keep Healthy!

4. Narasumber : Instruktur senam di Yogyakarta, ahli gizi

5. Durasi : 24 menit +6 menit commercial break

6. Sinopsis :

Program magazine Living in

Health memberikan informasi tentang gaya hidup sehat. Dikemas dengan gaya yang menarik, membangun suasana tenang dengan penggunaan warna-warna dingin. Episode pertama bertujuan mengajak dan memberi pengetahuan singkat apa manfaat hidup sehat, dengan judul “Keep Healthy!". Minimnya waktu yang ada untuk berolahraga, pemilihan makanan dan pola makanan yang salah, tidak ada keinginan untuk berolahraga dan kurangnya informasi tentang kesehatan dapat membuat tubuh menjadi tidak sehat. Menggunakan bahan bahan alami dalam makanan dapat membuat tubuh menjadi sehat. Tidak hanya makanan, tetapi juga diimbangi dengan berolahraga, dan pengetahuan yang cukup tentang kesehatan sangatlah membantu dalam merawat tubuh dari dalam diri dan dari luar. Mengajak penonton untuk mengubah cara hidup dengan hidup yang sehat dengan nyaman dan enak. Menggunakan kenyamanan, ketenangan, kedamaian, sebagai unsur pendukung dalam mengubah pola makan sehat. Memberikan tayangan kesehatan yang komplit dengan adanya makanan, olahraga, perawatan tubuh dan juga pengetahuan tentang kesehatan.

\section{Tahap Perwujudan Karya}

Tahapan perwujudan program tv magazine "Living in Health" ini telah melewati beberapa proses yang dapat menjadi satu kesatuan sesuai dengan Standar Operational Procedur seperti, praproduksi, produksi, pasca produksi. Ketiga tahapan penciptaan karya tersebut harus dilewati, karena saling terhubung untuk mewujudkan hasil yang direncanakan.

\section{Pra-produksi}

a. Ide

Langkah awal untuk memulai perwujudan karya adalah proses pencarian ide. Ide dapat berasal dari mana saja baik itu dari pengalaman diri sendiri, kehidupan sehari-hari, issue yang berkembang, suatu kejadian, imajinasi, maupun dari tayangan televisi. Pencarian ide dari program tv ini berasal dari keinginan untuk membuat sebuah program televisi yang 
berisi tentang info gaya hidup sehat yang mulai diminati wanita modern, dan dapat dilakukan di rumah yang nyaman.

\section{b. Riset}

Riset dimulai dari apa yang menjadi perhatian utama dalam menjalankan gaya hidup sehat, permasalahan apa yang sering dihadapi oleh wanita modern jaman sekarang, dan juga kebiasaan yang sering dilakukan. Riset dilakukan dengan mengamati kegiatan wanita yang memperhatikan gaya hidup sehat di media sosial. Mencari tahu dari internet dan buku kesehatan, pola gaya hidup sehat yang aman dilakukan untuk orang yang akan merubah gaya hidup.

c. Pemaparan Konsep

Ide awal membuat nuansa homey adalah membangun kenyamanan ketika melakukan berbagai aktivitas sehingga dipilih nuansa homey dengan implementasi warna dingin dan netral. Setting menggunakan dapur, living room, dan taman belakang sebagai titik utama dalam program tv magazine ini. Perbedaan warna dalam setting dibuat untuk membentuk karakter dari setiap segmen.

d. Treatment danScript

Pembuatan treatment dan script disesuaikan dengan rubrik yang akan dibuat. Menentukan rubrik apa saja yang akan dibahas, lalu dijelaskan dengan treatment. Treatment tersebut menjadi acuan untuk membuat script atau naskah dalam format magazine. Script magazine dibagi menjadi beberapa segmen yang membatasi perpindahan rubrik. Script juga disesuaikan dengan durasi yang telah ditentukan setiap segmennya. Segmen pertama dan ke-tiga ditayangkan 8 menit sebagai rubrik utama, sedangkan segmen ke-dua dan ke- empat berdurasi 4 menit.

e. Pembentukan kerabat kerja

Pembentukan tim pada tanggal 30 April 2018, dimulai dengan brief secara personal, maupun diskusi dalam forum. Berkomunikasi dengan orangorang yang berkaitan dengan divisi yang bersangkutan menjadi penting untuk dapat mewujudkan konsep yang telah direncanakan

f. Timeline Schedule

Jadwal produksi pada tanggal 7 Mei 2018 jadwal dibuat menyesuaikan dengan jadwal tim produksi, lokasi, dan pemain sehingga jadwal tersusun dengan baik dan dapat menghemat estimasi waktu dan biaya.

\section{g. Rapat Produksi}

Rapat produksi diadakan 3 kali, yang pertama tanggal 8 Mei 2018 dengan agenda menjelaskan konsep yang akan dibuat. Rapat kedua tanggal 11 Mei membahas progres tiap divisi, sedangkan yang terakhir tanggal 13 
Mei 2018 syukuran dan prepare untuk shooting.

\section{Produksi}

Proses produksi merupakan tahap eksekusi setelah sekian proses yang telah dilalui di tahap praproduksi. Proses produksi program tv magazine "Living in Health" berlangsung selama satu setengah hari pada tanggal 13 Mei 2018 sampai 14 Mei 2018 berlokasi di Rumah Lio Homestay, Yogyakarta. Tim produksi dibagi menjadi 2 tim. Pada tanggal 13 Mei 2018 diadakan pengambilan gambar pack shot yang berisi bahan masakan yang diambil dengan topshot.

Pack shot dimulai pada pukul 21.00 WIB hingga pukul 06.00 WIB. Awalnya, jadwal pengambilan gambar packshot hanya pukul 21.00 WIB hingga pukul 24.00 WIB. Tetapi karena setting dan reset bahan makanan memakan waktu lama sehingga jadwal pack shot menjadi bertambah. Sedangkan tim kedua mulai prepare dan sarapan mulai dari pukul 07.00 WIB-20.00 WIB. Jadwal shooting diperkirakan selesai pada pukul 18.00 WIB tetapi terkendala dengan host yang sulit untuk menghafal, sehingga shooting berlangsung lama.

\section{Pasca-Produksi}

Tahapan akhir yang merupakan tahapan penyelesaian atau penyempurnaan dari tahap produksi. Tahapan ini dapat berupa editing gambar ataupun suara, pengisian grafis, ilustrasi musik, sound effect, dan evaluasi terhadap hasil produksi. Melalui kreativitas seorang editor, sutradara dapat bekerja sama untuk membangun kembali ke realitasan film ini. Hal-hal yang dilakukan sebagai berikut.

\section{a. Preview hasil}

Pada preview pada saat pasca produksi bertujuan untuk megamati adegan, gambar setiap take-nya. Setelah itu baru bisa diputuskan mana file atau data yang akan diambil dan dilanjutkan ke proses editing selanjutnya. Kesalahan yang dilakukan sutradara pada tahap ini adalah tidak melakukan preview setelah shooting di lokasi. Sehingga ketika ada gambar yang tidak fokus, sutradara tidak dapat memperbaiki lagi.

\section{b. Melengkapi gambar VT}

Gambar VT diambil setelah produksi selesai. Mulai dari mengumpulkan dan mengambil gambar dari supermarket terdekat, mencari di internet, tempat makan fast food, mengambil gambar vox pop. Hal ini dilakukan dengan jadwal yang tidak ditentukan karena mengingat pengambilan video ini dapat secara acak.

\section{c. Editing offline \& picture lock}

Pada tahap ini, semua bahan video yang telah diambil dipotong dan digabungkan menurut script yang sudah dibuat. Editor bekerja sama 
dengan sutradara untuk memilih gambar yang tepat dan baik. Pemilihan gambar menjadi mudah karena banyak variasi shot yang diambil.

d. Editing online

Proses ini adalah dimana tahap pengerjaan warna, memasukkan ilustrasi musik, penambahan efek animasi dan grafis serta finishing. Proses ini cukup menguras energi, karena sulitnya memilih backsound yang tepat, pembuatan grafis di luar kota, dan keterbatasan waktu menjadi sebuah tantangan bagi sutradara dan editor.

\section{e. Mixing Audio}

Proses akhir untuk memberikan efek audio yang lebih lembut dan sesuai. Proses voice over, narasi, telah di ambil pada saat istirahat shooting sehingga pada proses ini hanya untuk menyesuaikan narasi, voice over, dan jingle. Pada proses ini, sutradara dan sound director saling mengirim data karena posisi yang tidak memungkinkan untuk bertemu. Sehingga proses komunikasi menggunakan chatting dan pengiriman data memanfaatkan e-mail.

\section{Pembahasan Karya}

Proses praproduksi, produksi, dan pasca produksi yang telah dilalui menghasilkan sebuah karya seni program tv magazine "Living in Health". Semua konsep yang diterapkan dalam program tv magazine ini akan dipertanggung jawabkan sesuai dengan teori yang dipakai. Sesuai dengan judul „Membangun Nuansa Homey dengan Implementasi Warna Netral dan Dingin dalam Program TV "Living in Health", maka implementasi warna netral dan dingin diterapkan untuk membangun nuansa homey.

\section{Nuansa Homey}

Program TV Magazine"Living in Health" memberikan nuansa homey untuk membuat penonton menjadi nyaman untuk melakukan dan menerapkan gaya hidup sehat. Kenyamanan yang dibangun di dalam rumah ini meliputi setting artistik, Property, wardrobe, juga pembahasan dalam rubrik.

a. Segmen 1 (Rubrik Tasty Heatlhty)

Rubrik ini merupakan rubrik utama dan fix items dalam setiap episode, sehingga rubrik ini diberi durasi yang lebih panjang dibanding rubrik yang lain. Rubrik ini membahas tentang makanan sehat yang dapat dibuat dirumah. Nuansa homey yang dibangun dalam segmen ini meliputi menu makanan yang dibuat, setting yang dibangun, serta pemilihan Property yang ada. 


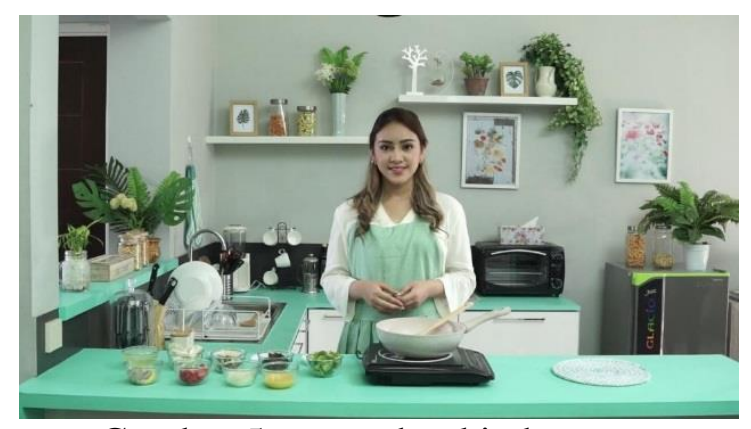

Gambar 5 screenshot kitchen set

\section{b. Segmen 2 (Rubrik Beauty)}

Pembentukan living room yang nyaman didukung dari beberapa elemen sehingga kesan homey tercipta. Dimulai dari pemilihan sofa yang sisinya lengkung, berbusa tebal sehingga terlihat empuk dan nyaman. Meja yang dipilih juga memiliki sisi lengkung menghindari kesan kaku pada ruangan. Ditambah nakas dengan warna senada sebagai pemanis ruangan.

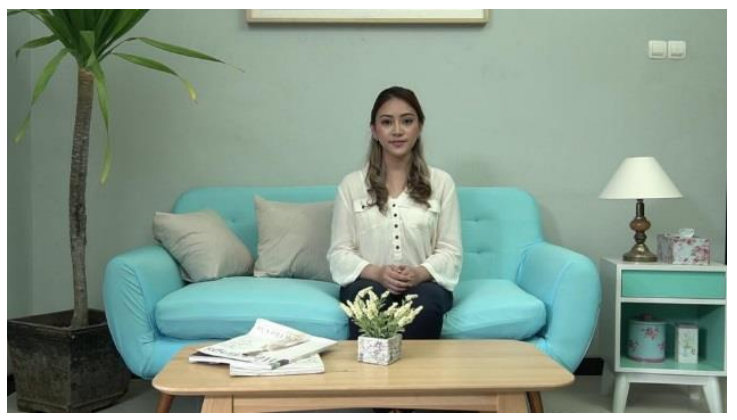

Gambar 6 screenshot setting living room rubrik beauty

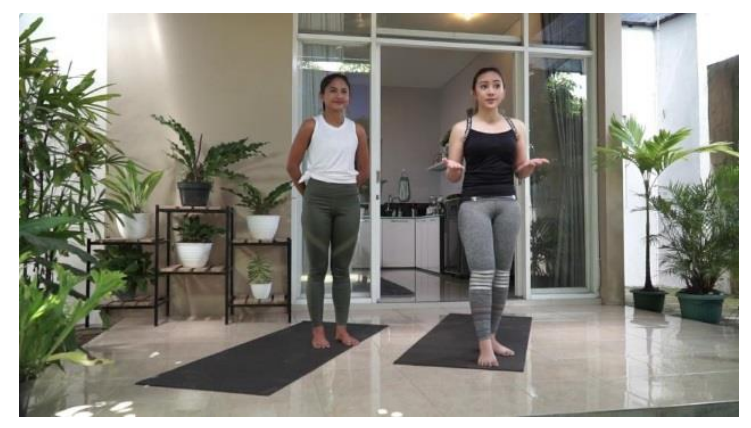

Gambar 7 screenshot setting rubrik movement

\section{c. Segmen 3 (Rubrik Movement)}

Pembangunan nuansa homey pada setting ini dibuat dalam set taman belakang rumah. Sehingga shot diperlihatkan teras belakang rumah dengan background dapur di dalam rumah. Taman belakang juga masih di dominasi dengan tanaman hijau sebagai lambang alami, kesegaran dalam rumah. Sehingga tanaman yang sengaja diletakkan di taman belakang untuk memengaruhi orang di sekitarnya untuk bergerak lebih aktif dan mendapat dampak yang positif.

d. Segmen 4 (Rubrik Fakta dan Mitos)

Segmen penutup adalah informasi mitos dan fakta, tentang kebiasaan dan pemahaman masyarakat yang masih salah. Masyarakat akan diberikan suatu masalah, lalu ada ahli gizi yang akan menjelaskan yang benar dan salah. Setting utama dalam segmen ini adalah reading corner.

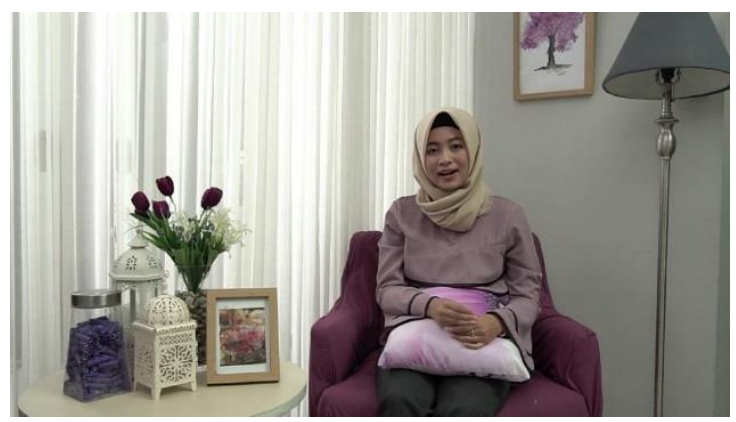

Gambar 8 screenshot setting reading corner 


\section{Penutup}

Perwujudan karya "Living in Health" ini dipandu oleh seorang host wanita yang mempraktekkan beberapa instruksi pembahasan. Setiap rubrik dibedakan dengan warna setting, motion graphic yang mempunyai makna dan lambang masing-masing. Sehingga warna-warna ini mendukung nuansa homey yang ingin dibangun. Masih banyak kekurangan-kekurangan dalam perwujudan program TV magazine ini, namun semua kru yang terlibat dalam produksi mampu berkomunikasi dengan baik demi kelancaran produksi.

Nuansa homey merupakan suasana seolah-olah rumah pribadi yang nyaman, dalam penerapannya ukuran sebuah ruangan yang homey dan nyaman dapat bermacam-macam tergantung dari pengguna ruangan tersebut. Program TV ini mengambil arti homey nyaman secara umum yaitu ketika seseorang atau kelompok telah terpenuhi kebutuhannya dan leluasa untuk melakukan aktivitas. Homey dalam program ini menerapkan konsep minimalis.

Warna yang diterapkan dalam setiap set mempunyai karakteristik masing-masing untuk mendukung nuansa homey yang ingin dibangun. Warna dingin membawa sifat yang melankoli, sehingga ditambahkan warna netral untuk menambah kesan clean dan menyeimbangkan warna dalam setting.
Program ini disegmentasikan untuk wanita, tetapi memilih untuk menggunakan warna dingin yang maskulin. Warna dingin mempunyai karakter dan lebih banyak digunakan lambang-lambang untuk kesehatan, kealamian, dan lain-lain. Sehingga tidak menggunakan warna-warna hangat yang cenderung disukai oleh para wanita. Efek yang ditimbulkan ketika menerapkan warna dingin dan netral dalam program tv ini adalah kesan kesegaran yang diberikan dalam setiap segmen.

\section{Daftar Pustaka}

Anditya. Ide Warna Rumah Gaya. Yogyakarta: CV Andi Offset, 2016.

Bachrens, Inge Tumiwa. Eating Clean. Jakarta: PT Kawan Pustaka, 2017.

Bachrens, Inge Tumiwa. Panduan Mudah Eating Clean. Jakarta: PT. Kawan Pustaka, 2017.

Baksin, Askurifai. Jurnalistik Televisi Teori dan Praktik. Bandung: Simbiosa Rekatama Media, 2013.

Darwanto, Televisi sebagai Media Pendidikan. Yogyakarta: Pustaka Pelajar, 2011.

Fachruddin, Andi. Dasar - Dasar Produksi Televisi. Jakarta: Kencana, 2012

Kartika, Dharsono Sony. Seni Rupa Modern. Bandung: Rekayasa Sains, 2004.

Latief, Rusman, dan Yusiatie Utud. Siaran Televisi Non-Drama. Jakarta: PT Adhitya Andrebina Agung, 2015. 
Lutters, Elizabeth. Kunci Sukses Menulis Skenario. Jakarta: PT Grasindo Anggota Ikapi, 2010.

Mascelli, Joseph V, terj. H.Misbach Y.B. The Five C's Of Cinematography, Jakarta:FFTV IKJ, 2010.

Morissan. Manajemen Media Penyiaran. Jakarta: Kencana Prenada, 2008.

Naratama. Menjadi Sutradara Televisi. Jakarta: PT Grasindo Anggota Ikapi, 2004.

Nugroho, Sarwo. Manajemen Warna dan Desain. Yogyakarta: CV Andi Offset, 2015.

Nugroho, Sarwo. Teknik Dasar Videografi. Yogyakarta: CV Andi Offset, 2014.

Nursalim. Deadline Menaklukkan Rintangan Menulis Berita Televisi. Yogyakarta: CV Andi Offset, 2015.

Pratista, Himawan. Memahami Film. Yogyakarta: Homerian Pustaka, 2008.

Sanyoto, Sadjiman Ebdi Sanyoto. Dasar-dasar Tata Rupa \& Desain (Nirmana). Yogyakarta:Pengadi dan Iid, 2005.

Wibowo, Fred. Teknik Produksi Program Televisi. Yogyakarta: Grasia Book Publisher, 2014.

Wibowo, Ibnu Teguh. Belajar Desain Grafis. Yogyakarta: Notebook, 2015.

\section{Daftar online}

https://www.dekoruma.com/artikel/ 70683/dekoruma-ideas-apartemenminimalis-natural (diakses pada 16 Juli 2018, 05.03 WIB) https://www.greenwood.id/rumahminimalis/ (diakses pada $16 \mathrm{Juli}$ 2018, 03.46 WIB)

https://kuliahbahasainggris.com/pe njelasan-singkat-tentang-home-madehomey-home-sweet-home-dalambahasa-inggris/ (diakses pada tanggal 16 Juli 2018, pkl 12.26 WIB

https://www.google.co.id/amp/s/12 19251008ketutryanbudhisaputra.word p ress.com/2015/03/10/teori-dankonsep-perancangan-ruangdalam/amp/ diakses pada 16 Juli 2018, pkl 12.37 WIB)

http://www.homedesigning.com/30-blue-living-roomsto-relax-the-mind- body-and-soul (diakses pada 16 Maret 2018, 23.12 WIB)

http://www.aconsideredlife.co.uk/2 017/03/how-to-make-your-minimalisthome-feel-homey.html (diakes pada 16 Maret 2018, 23.43 WIB)

https://www.vemale.com/kesehatan 171786-mengenal-arti-clean-eatingdan-manfaatnya.html (diakses pada 22 Maret 2018, 23:02 WIB)

https://hellosehat.com/hidupsehat/nutrisi/cara-menjalani-cleaneating/ (diakses pada 23 Maret 2018, 00:02 WIB)

https://flyonz.com/2014/01/19/calis thenics-penting-nggak-sih/ (diakses pada 23 Maret 2018, 00:53 WIB)

http://www.alodokter.com/gayahidup-sehat-bisa-anda-mulaisekarang\# (diakses pada 26 Maret 2018, 19:47 WIB)

http://interiordesign.id/7-ciri-khasdesain-interior-rumah-skandinaviayang-mempesona-sekaligusmenginspirasi/ (diakses pada 28 Maret, 13.08 WIB) 
http://interiordesign.id/gaya-desainminimalis-ruang-keluarga/ (diakses pada 28 Maret, 16.31 WIB)

http://interiordesign.id/gaya-desaininterior-minimalis-vs-skandinaviagaya-desain-interior-mana-yang-andapilih/ (diakses pada 8 April 2018, 19.26 WIB)

http://interiordesign.id/desaininterior-ruang-keluarga-skandinavia/ (diakses pada 8 April 2018, 20.19 WIB) 